\title{
WRONGFUL OMISSION AS A CONDITION FOR TORT LIABILITIES
}

\author{
Sibilla Buletsa* \\ Uzhgorod National University, Law faculty,Ukraine,E-mail: sibilla.buletsa@uzhnu.edu.ua
}

\section{Svitlana Hrinko}

Leonid Yuzkov Khmelnytskyi University of Management and Law, Ukraine, E-mail: svetgrin27@ukr.net

\section{Ruslan Hrinko}

State Border Guard Servise of Ukraine, Ukraine, E-mail: rvg14@ukr.net

\section{Halyna Anikina}

Leonid Yuzkov Khmelnytsky University of Management and Law, Ukraine, E-mail: galinaanikina07@gmail.com

\section{(Received: April 2020; Accepted: June 2020; Published: June 2020)}

\begin{abstract}
As omission of a person is a certain manifestation of his/her internal will from outside. Exactly through inactivity, the internal will of a person materializes due to which a person becomes a participant of public relations. At the same time in the absence of external expression of will inactivity of a person can not cause the occurrence of legal consequences, in particular, to be examined as a reason of origin of tort liabilities. If a person enacted because of negligence or poor awareness, it should be defined: whether a person knew or had to know about the necessity to perform a certain action. Accordingly, if a person possessed such knowledge this form of behavior will be treated as guilty omission, if not - this is an example of innocent omission. Responsibility for illegal omission can arise only when appropriate persons are included in the system of civil and legal relationships, thus are the subjects of civil relations. Damage caused by "reflexive movements" testifies the carelessness of a person to his/her behavior, which reflects his/her will. Therefore, such behavior of a person is considered to be wrongful.
\end{abstract}

Keywords: torts, wrongful omission, causal omission, causal inactivity, civil relations, damage.

\footnotetext{
${ }^{*}$ Corresponding author: Sibilla Buletsa. E-mail: sibilla.buletsa@uzhnu.edu.ua
}

Copyright (C) 2020 The Author(s). Published by VGWU Press

This is an Open Access article distributed under the terms of the Creative Commons BY 4.0 license (Creative Commons - Attribution 4.0 International - CC BY 4.0) which permits unrestricted use, distribution, and reproduction in any medium, provided the original author and source are credited. 
Buletsa, S., Hrinko, S., Hrinko, R., Anikina, H., (2020)

Wrongful omission as a condition for tort liabilities

\section{Introduction}

For effective application of the institute of tort liabilities, it is necessary to have a coherent idea of all the conditions of their occurrence. So, you need to be clear about all the features of a tort (offense), among which the most important is the unlawful behavior of the harm-doer.

Tort liabilities can occur not only in case of commission of a wrongful act but also of wrongful omission. Infliction of harm by omission is not such an exclusive phenomenon as it may seem at first glance, correctly noted by O. S. Ioffe. At the same time, illegal omission sometimes is more dangerous than illegal act [1]. Therefore, Roman lawyers paid special attention to consideration of such cases of harm (delicta in ommissione), trying to stop any attempt to reduce or fully release from liability for such offenses. The Roman jurist Gaius in his maxims wrote that the one who performed surgery successfully, but deprived the patient of further treatment, was not released from liability, therefore, was considered guilty (D. 9. 2. 8). So, the act of omission was not merely meant as subject passivity, but it lies in omission to perform the act imposed as a duty on a person - the duty of a doctor to provide medical care to the patient.

History of development. Ideas of Roman lawyers influenced the formation of the concept of the wrongful omission in soviet and modern Civil Law of Ukraine. Under the Roman legal tradition, the institute of the law of torts was built also according to the civil legislation of pre-soviet times. In particular, in the draft of the Civil Code of Russian Empire 1905 illegal omission was defined as the omission of the act the performance of which was required by law or the regulations of appropriate authority (P. 2 Art. 2601). The omission as a condition for occurrence the duty to undo the damage is noted in the Civil Code of Ukraine in Articles 1166, 1167, 1173, 1174, 1176,1190 . Indication of omission as a condition for occurrence tort liability is provided by the Civil Codes of Uzbekistan (P. 1 Art. 985), Tadzhykistan (P. 1 Art. 1079), Kazakhstan (P. 1 Art. 917), Azerbaidzhan (Art. 1096.1). Interesting is the approach of the Civil Code of Moldova, according to which any mention of omission as a legally meaningful form of a person's conduct is absent. However, the body of public authority or official entrusted with the duty to indemnify damage sustained as unlawful administrative act and unsettled application by the specified time (P. 1 Art. $1404 \mathrm{CC}$ of Moldova). So in the latter case, it is referred to as the omission.

Causal omission. Civil and legal doctrine is otherwise debatable concerning the nature of "causal omission" (illegal or legal, guilty or innocent), and also concerning a relation of omission with rules of law and human will. Scientists think that responsibility must be established for the illegal omission I. B. Novitskyi, L. A. Lunts (1950), V. O. Tarkhov, K. A. Fleishyts, M. D. Sharhorodskyi) [2], illegal and 
Buletsa, S., Hrinko, S., Hrinko, R., Anikina, H., (2020)

Wrongful omission as a condition for tort liabilities

legal omission (Ya. M. Shevchenko) [3], guilty omission (B. S. Antimonov) [4], guilty and innocent (I. B. Novitskyi, L. A. Lunts), (Ya. M. Shevchenko) [5].

Taking into account the information mentioned above it should be stated that the question of the illegal inactivity as a condition of origin of tort obligations is actual and requires deep research which is the aim of this scientific work. Accordingly, the basic tasks of this research are to describe basic conceptions of "causal omission", to define the nature of "causal omission", find out the connection of omission with the norms of law and human will.

\section{Causal inactivity}

The following scholars denied the existence of "causal inactivity" in a civil legal doctrine: B. S. Antimonov, S. Ye. Dontsov, M. Ya. Marinina, K. A. Fleishyts and other scientists, and among the theorists of law such position was occupied by M. D. Sharhorodskyi. They considered that a non-performed action can not be a reason of one or other consequence, that is why it must be mentioned about the causal connection of harm with a fact which was not removed by a responsible person.

M. D. Sharhorodskyi was categorical in his ideas and asserted that as a result of omission there is no causal connection at all, and the other type of dependence of the phenomenon takes place. He explained it in a certain way: omission of a person, which had to prevent the cosialy-dangerous consequences, takes responsibility not because he/she inflicted a result, but because a subject did not prevent the result if this person was obliged to do it. Therefore, the attempts to ground the presence of the reason for omission as an obligatory element for responsibility in law - are groundless. Disagreeing with authors who acknowledge a task as an omission, M. D. Sharhorodskyi mentioned that the omission is understood not as an objective phenomenon of the external world, but as a legal category which is based on obligatoriness. Accordingly, considering a task as an omission the author at once must answer a question, whose omission inflicted a result, so as the whole world is inactive. And, answering this question, he necessarily will come to the conclusion that inflicts that person, who had to act.

The main disadvantage in the above-mentioned position of scientists I. B. Novitskyi and L. A. Lunts saw that, if to deny "causal inactivity", then it should be admitted that all cases of responsibility for losses, inflicted by non-fulfillment or expiration should be examined not on principles of causal connection, but according to the other grounds. So the reimbursement of losses in such cases was impossible to prove on the basis of reliable data, and only on suppositions about the possible course of events. Only in case of defective performance of (positive action), it was possible to talk about causing of losses.

K. A. Fleishyts did not share the opinion of M. D. Sharhorodskyi in relation to the denial of the existence of causal connection at "causal inactivity", being at the same 
Buletsa, S., Hrinko, S., Hrinko, R., Anikina, H., (2020)

Wrongful omission as a condition for tort liabilities

time the supporter of denial of such category. In her opinion, only that result should be taken into account, which is causally predefined by a fact which it is not removed, - the concept of causal connection is used in the same way as the infliction of harm by positive action. In such a case, it is considered the part of the result, which would be removed on the condition of implementation of non-performed action. The question concerns some predictable causal connection of facts, however about such connection which, repeatedly appeared in other homogeneous cases. In other words, their supposition is based on objective causal connection. Similar position of K. A. Fleishyts took S. Ye. Dontsov and M. I. Marinina. They specified that if a condition which facilitated an origin or increasing of harm was expressed by inactivity, then property responsibility comes not for the inflicted harm, but for unprevented harmful consequence.

Later K. A. Fleishyts took up a quite original position. She considered that the connection between inactivity and harm was causally-accidental. However, her reasoning was absolutely unacceptable in legal literature, even among the supporters of the conception of denial of "causal inactivity". M. D. Sharhorodskyi asserted in particular, that if between inactivity and result causal connection was possible, then it could be both accidental and necessary.

Among modern researchers of omission as forms of legal behavior S. A. Kapitanska assumes, following K. A. Fleishyts, except necessity, also the presence of an accidental connection between omission and consequences. In this connection, the researcher did not examine inactivity as a reason which can directly cause the ensuing consequences. In her opinion, "inactivity plays the role of the condition of possible consequences (what can not generate the phenomenon, and, accompanying reasons in space and time, provide their development, necessary for the origin of consequence)".

Denying "causal inactivity", B. S. Antimonov refers to an indication of F. Engels in "Anti-During" that reason which does not operate is not a reason [6]. According to I. B. Novitskyi and L. A. Lunts, a researcher emanated from mechanical transference of correct for understanding regularity of nature of the position to the study of the public phenomena [7]. They pointed out the ideas of A. A. Piontkovskyi for the argumentation of their position to this question: "Omission in public relations at certain terms is certain behavior. In the society under labor division, the omission of a person can cause certain changes in the outer world. Under the labor division at the plant a conveyor can break off work not only when it was damaged by active actions, but also when some of the workers do not perform production operation which was assigned to them" [8]. Therefore, I. B. Novitskyi and L. A. Lunts (1950) explained that in each of these cases there is difficult composition of behavior, where an omission is combined with harmful positive actions, that is why in most cases it is 
Buletsa, S., Hrinko, S., Hrinko, R., Anikina, H., (2020)

Wrongful omission as a condition for tort liabilities

impossible even to separate one element from another and define, which of them caused this result [9].

The supporters of denial of the existence of "causal inactivity" see only the results of the natural order, without noticing other consequences by doing so. In the opinion of B. S. Antimonov, when dealing with the problem of causal connection it is necessary to reject the concept of losses as illegal consequences, as far as damage and losses are legal concepts and they do not occur in natural connection of things. So, he considers that causality exists only in the natural connection of things, and that is why it is absent in the field of public relations.

O. S. Ioffe correctly disapproved of such grounding, he mentioned that the certain state of the violated relation is expressed in losses, and this state has objective character regardless of what legal-economic assessment it is subjected to. "If, not limited to the natural consequences, - a researcher explained, - to appeal to the natural result of an offense, then it will fully be obvious, that it could be caused by behavior, and only human behavior, regardless whether it is expressed in the form of action or omission [10].

The existence of "causal inactivity" in tort liabilities is acknowledged by O.S. Ioffe, I.B. Novitskyi, L.A. Lunts, H.K. Matveev, Ya.M. Shevchenko and other researches [11]. According to their opinion, it is necessary to set a causal connection of damage and omission to evoke liability to recover damage. In other words, the reason for harmful consequence is passivity - the absence of necessary activity under certain circumstances. Such legal passivity in the literal sense is inactivity in the behavior of a subject - the absence of activity in the process of realization of legal norms. Only the absence of the possibility of a subject to realize a necessary action excludes a matter of his/her liability.

On the example of parents' omission Ya.M. Shevchenko proved that a causal value is characteristic of inactivity as a form of behavior of a person in the society [12]. "Omission of parents in rearing and caring of children can not inflict damage itself (as distinguished, for example, from omission at the property concealment, at negligence, etc.). Damage arises directly from the actions of children. But as these actions are the result of parents' omission, so the damage caused by children, is the consequence of inactivity of parents in rearing and caring of children with damage" [13].

Supporting causal omission, O.S. Ioffe, taking into account its material essence, it presents the certain form of a person's participation in public relations, influences the dynamics of these relations and due to it predetermines the occurrence of the known consequences of public order. The scientist accentuated that everybody enacts, but not all of them are the participants of the disordered public relation [14]. Such a position is correct, as the omission of a person is a certain manifestation of his/her internal will from outside. Exactly through the inactivity, the internal will of 
a person materializes due to which a person becomes a participant of public relations. At the same time in the absence of external expression of will inactivity of a person can not cause the occurrence of legal consequences, in particular, to be examined as a reason of origin of tort liabilities. For example, the will of a person for nonfulfillment of something preserved in his/her mind, is not inactivity, as there is no external expression ("I do not want to do it"). And in the case when the will of a person is manifested in deprival of performing something ("I do not want to do it and do not do it"), then his/her omission takes place which can cause certain consequences. Exactly through inactivity behavior of a person is expressed, that is why omission can be active. Roman lawyers shared the same approach, according to them, the intention to carry out an action or hold back from it, if it was neither informed nor performed was not considered a tort action: de internis non judicat praetor [15].

After defining a question about the existence of "causal omission", a character of this inactivity should be investigated.

The criterion of accordance of omission to the rules of law was taken as a basis for the division of inactivity as grounds of origin, change and termination of civil legal relationships, that was once offered by $\mathrm{O}$. O. Krasavchikov. He distinguished: 1) illegal inactivity - omission; 2) legitimate inactivity - silence. The scientist considered that under legitimate inactivity in every separate case the legal significance of legitimate "silence" as a legal fact arises only at presence of the direct regulations of rules of law, which legal consequences in this connection prescribe [16]. Confirmation of significance of the conclusion made by the scientist can be found in the current CC of Ukraine of 2003: "In cases, set by an agreement or law, will of the party to the performance of a legal transaction can be expressed by his/her silence" (P. 3 Art. 205).

Substantial contribution to national science in the field of research of forms of legal behavior and legitimate inactivity in particular, was done by C. A. Kapitanska [17]. Special attention deserves the thesis research of the Russian scientist A. D. Prusakov, where he considered action and omission not only as a form of expression of legitimate and illegal behavior but also as pair categories which express the essence of legally meaningful behavior [18].

Supporting the division of omission into legitimate and wrongful, R. A. Khannanov thought that volitional moment in omission should be taken into account. So it is referred to as silence in the meaning of approval, encouragement, admiration, but not indifference. The scientist distinguishes four forms of omission depending on the perception of inactivity and its consequences by a person: 1) quilty omission; 2) innocent omission; 3) omission of ignorance or poor awareness; 4) mental or unconscious omission. In addition, on the basis of harm doers form of guilt, he 
Buletsa, S., Hrinko, S., Hrinko, R., Anikina, H., (2020)

Wrongful omission as a condition for tort liabilities

divides guilty omission (legitimate and illegal) into 1) intentional legitimate omission (silence, assumption) and careless (non-interference, innuendo); 2) intentional illegal omission (negligence, avoidance, weakening) and careless (inaction) [19].

We do not share the opinion of R. A. Khannanov in relation to a division omission into separate groups of ignorance or poor awareness, and also mental or unconscious omission. If a person enacted because of negligence or poor awareness, it should be defined: whether a person knew or had to know about the necessity to perform a certain action. Accordingly, if a person possessed such knowledge this form of behavior will be treated as guilty omission, if not - this is an example of innocent omission. Responsibility for illegal omission can arise only when appropriate persons are included in the system of civil and legal relationships, thus are the subjects of civil relations. And for this purpose, they must be legally able and capable, in particular delictual capacity. Persons who are unable to understand the value of their actions and (or) control them are excluded from the system of civil and legal relationships, that is why no questions can arise according to their delictual capacity. At the same time, there is no necessity to outline a separate group of omission based on madness and unconsciousness.

In the offered division of omission replacement of objective category of "omission" and subjective category "guilt" is observed. Such replacement is inadmissible, as omission and guilt are independent elements of one complex phenomenon. Thus, the omission is a form of behavior of a person, and through his/her internal will is expressed, and guilt is a volitional attitude of a person towards his/her omission and its consequences: "will - omission - consequence".

In the opinion of B. S. Antimonov, our law, speaking about the cause of damage with inactivity, non-performance, uses only a brief idiomatic expression which is included in everyday language. Actually, in such cases we always talk only about quilty inactivity, that is about the omission, and responsibility is put not for action (it is absent) and not for its consequences (there is nothing to ensue), but for events which naturally took place in the absence of action (the action had to be performed by an obliged person, however, it was omitted) [20]. That is why such a position of the scientist was not supported by I. B. Novitskyi and L. A. Lunts. In their opinion, according to the Article 404 of the Civil Code the responsibility for the innocent cause of the damage (by an action or omission) evidently refutes a statement, that law sets responsibility only for quilty omission (being responsible for the omission, a person is liable not only for guilt but also for its infliction) [21]. So, they acknowledge responsibility for the guilty and innocent omission.

It's impossible to agree with such grounding of the wrong grant of guilty nature to responsibility for damage, inflicted by omission. As clearly suggested by K. A. Fleishyts the responsibility under the Art. 404 of the Civil Code in general is not a 
responsibility for the behavior of a proprietor of the source of the caused danger, as a proprietor will bear the responsibility for harm, inflicted by the action of the source of the increased danger. For responsibility under the Art. 404 it is necessary, that harm was inflicted not by the behavior of a proprietor of the source of the increased danger, but by the action of the source of the increased danger, which a proprietor uses in some activities. It means that a matter of a proprietor's omission should not arise, that is why an explanation of the innocent nature of "causal omission" is inappropriate on such an example.

On this occasion V. O. Tarkhov mentioned that the accent is done on the other conditions of origin of obligations from the infliction of damage, and causal connection as an obligatory condition of these obligations loses its independent nature. He considers that deciding a question about responsibility, all conditions of origin of obligations from the infliction of harm should be taken into account jointly, but they should be examined separately. Otherwise, one condition can be replaced by the other, which will result in a wrong conclusion [22]. To agree with such a single-valued denial of introduction to the category of inactivity of features of illegality and guilt is fully impossible. Firstly, the acknowledgment of guilty omission means forming legal construction of omission on principles of guilt, but guilt is an independent subjective condition for the origin of tort liabilities (as correctly mentioned by V. O. Tarkhov). Secondly, for the acknowledgment of omission by the condition of origin of tort liabilities it must be of illegal nature, as "the majority enacts", but only persons who caused damage bear responsibility. In addition, illegality is not an independent condition of origin of tort liabilities but is the obligatory feature of behavior of a person for bringing him/her to tortious liability.

Thoughts of V. M. Kudriavtsev deserve special attention, who thinks that infliction of harmful consequences with omission creates an objective side of corresponding crime and at the same time presents an actual foundation of intention or carelessness [23]. In other words, the scientist examines illegal inactivity as a foundation for the determination of the form of guilt that should be definitely supported.

Normative and illegal character is given to "causal inactivity" by I. B. Novitskyi and L. A. Lunts, so responsibility for infliction of damage by omission appears when the law obligates a person to perform a certain action. In such conditions, according to scientists' opinion, an action of a person becomes a necessary chain in existing public relations, gains the nature of regular public phenomenon [24]. As T. V. Tsereteli mentions, excluding one's activity from such regularity, the omission of a person becomes an active, substantial condition for ensuing damage [25].

Ya. M. Shevchenko provides «causal omission» not only with illegal but also with legitimate character. She tried to prove her opinion on the basis of specific cases 
Buletsa, S., Hrinko, S., Hrinko, R., Anikina, H., (2020)

Wrongful omission as a condition for tort liabilities

from judicial practice on damages recovery caused by children. In her view, parents bear responsibility, not for their behavior, therefore, it does not matter what kind of behavior it was - guilty or innocent and whether it was causally related to the actions of parents or not [26].

The form of legal behavior according to «causal omission» is traditionally associated with the passive form. This position is dominant in all branches of law. In particular, according to H. F. Timeik, a researcher in criminal law, there is no active point under omission, which would lead to the action of physical, chemical and other regularities of the objective world, and without this, the causal relationship is impossible [27].

Among scientists, however, there can be found other considerations regarding the form of omission expression. For example, O. S. Ioffe perceived not only passive but also active element in omission. On this occasion, he noted that if one considers omission not in isolation but in close connection and collaboration with public relations in the sphere of which the inactivity was allowed, its active quality will be obvious [28].

A similar position was taken by V. M. Kudryavtsev. In his opinion, it is groundless to deny an active element in omission, as causality is associated only with an active environmental change. He believes that the emergence of unambiguous recognition of inactivity in the form of passive behavior is due to the fact that scientists do not distinguish the difference between the philosophical and physical concept of causality [29].

Thus, the wrongful omission can be the cause of the occurrence of harmful consequences in the case of tort committal. Acting as an independent condition for the occurrence of tort liabilities, the omission can be expressed both in passive and active forms of legal behavior.

Inheriting the ideas of Roman jurists in modern civil law omission acquires legal value only in the situation that is within the scope of legal regulation. That is, the omission is a normative category [30]. Regulatory law mediating passive behavior of the subject manifests itself in such a way: 1) law allows lawful omission, that is permits to misuse some conduct demonstration; 2) law prohibits wrongful omission, that is, attributes the obligation to perform a particular action; 3) law prescribes lawful omission that forbids socially harmful actions [31].

The wrongful omission is treated as non-performance of actions prescribed to this subject, which are considered to be his obligation. The latter may arise, firstly, from direct instructions of law; secondly, from a contract or an employment agreement. Responsibility for damage caused by omission may be born only to the third party suffered from damage, but not to the counterparty under the contract (to him the offender bears the contractual liability). Thirdly, the duty to perform certain actions can arise from situations created by a person himself, for instance, an experienced swimmer takes the responsibility to perform certain actions when lures a swimmer- 
Buletsa, S., Hrinko, S., Hrinko, R., Anikina, H., (2020)

Wrongful omission as a condition for tort liabilities

novice to long-distance swimming, or an experienced climber takes for a mountain walk an inexperienced in this sports person and thus assumes a duty to assist him in cases of emergency. The nature of the failure to render aid in such circumstances is unlawful [32].

Concerning the latter case, the illegality of such action is omitted, and therefore its implementation does not evoke the necessary to apply legal sanctions. A dangerous situation that leads to the obligation of persons concerned to carry out other activities acquires the value of a legal fact. Omission committed under circumstances that caused the onset of harmful consequences is the basis for the adoption of civil penalties, in some cases even criminal ones [33].

Sometimes law imposes upon an individual concerned the obligation to take certain actions to prevent harmful consequences that could arise due to the hazardous situation, which arises out of the activities of these persons. Such standards include rules on labor protection, safety rules, sanitation, rules of the road. An example of such special rules is performed by Article 53 of the Trade Navigation Code of Ukraine, which obliges the captain of a vessel: 1) to assist any person observed in the sea who is threatened with death; 2 ) to make efforts to help the victims when he is reported that the victims need help. Failure to do so is treated as wrongful omission, and therefore part 3 of the Article indicates that non-compliance with these actions (duties) the captain shall bear the liability established by law.

Omission is found to be unlawful if it detects consciousness and will of a person. When a person due to objective circumstances could not act, then it cannot be deemed illegal. This feature is sometimes expressly referred to in the rule, which imposes a duty to act. Therefore, non-performance of certain actions by a person who bears responsibilities to realize them according to one of the circumstances mentioned above is illegal with all the ensuing consequences. Ideas of the Roman jurisprudence view such a requirement to the illegal character of omission. The maxim of Gaius should be cited here: the one who performed the surgery successfully, but deprived the patient of further treatment, was not released from liability, therefore, was considered guilty (D. 9. 2. 8). It means that Roman lawyers did not reduce omission to a passive person, it was treated as a lack of action implementation assigned to him/her.

It happens sometimes that a person is obliged to perform certain actions, but he/she does not do so due to objective, physical inability to implement them. In such circumstances, a matter of responsibility of a person who did not act must be resolved negatively.

By the Trade Navigation Code of Ukraine (Article 53), the captain will perform the duty to render aid to a person observed in the sea who is threatened with death, under the condition: if he can do it without danger to his vessel, crew and passengers. If 
Buletsa, S., Hrinko, S., Hrinko, R., Anikina, H., (2020)

Wrongful omission as a condition for tort liabilities

such a possibility is excluded, failure to render aid is not considered unlawful. It should be noted that according to the Criminal Code of Ukraine, providing responsibility for failure to render aid to a person in a life-threatening condition links it with the physical ability to perform these terms: «had the opportunity to render aid», «to provide such aid when possible», «failure to render aid without a good reason». The absence of such a clause in the rule which imposes a duty to act, cannot be a ground for not taking into account objective possibility to act. The opposite conclusion would contradict the very essence of human behavior [34].

Thus, the mere fact of imposing an obligation to perform certain actions is not enough for imposing liability for the inaction of an individual. Obligatory condition of granting omission a wrongful nature is to face an opportunity to implement it under particular circumstances.

Taking into account this condition, O. S. Ioffe indicates in the definition of wrongful omission that omission is found to be unlawful when it is omitted by a person who could and had to act (highlighted, - O. S. Ioffe). Thus, the term "had to" is defined by the scientist as a legal criterion involving the duty to perform certain actions, and "could" is treated as a physical criterion, which implies the physical possibility of their realization [35]. However, a lack of possibility of a specific individual to carry out an obliged action precludes the wrongfulness of omission.

This position of O. S. Ioffe has caused some objections to M. N. Semiakin. We do not share the criticism of M. N. Samiakin relative to the position of O. S. Ioffe. M. N. Semiakin identifies the "ability" of a person to act in a certain way according to the subjective signs of a category "guilt". However, guilt is a volitional attitude of a person to his behavior and its consequences. Performance or non-performance of the duties depends on the inner will of a person. Guilt is connected with omission through the volitional factor: will is expressed externally by means of inaction and the question of a person's guilt arises. And "possibility" is an external condition of the real capacity of a subject to act, that is an objective category, independent of a person's will, as it depends on the surrounding circumstances, on the place in social relations. If the omission of a person is connected with the will of an individual (inactivity is defined by the existence of guilt and its forms), "possibility" or "impossibility" is a condition of the illegality of omission. That is, "guilt" and "possibility" are the elements of different phenomena (subjective and objective) that are interconnected through illegal omission. If an obliged person had "possibility" to act in a certain way but did not act, then omission is wrongful, and a person is liable for his/her guilt. Thus, the volitional attitude of a person to the character of his/her omission but not "possibility" will determine his/her guilt, since the latter only affects the wrongfulness of such inaction. Regarding the second remark of the scientist, we believe that treating the issue of "possibility" as a condition of the illegality of the omission of mentally disordered persons is not advisable due to their 
Buletsa, S., Hrinko, S., Hrinko, R., Anikina, H., (2020)

Wrongful omission as a condition for tort liabilities

unliability to tort. Actions of such persons are deprived of will, but will and awareness are mandatory features of omission and guilt. Damage caused by "reflexive movements" testifies the carelessness of a person to his/her behavior, which reflects his/her will. Therefore, such behavior of a person is considered to be wrongful.

\section{Conclusions}

Thus, imposing liability for the omission of an individual requires three conditions: a) existence of a duty to take certain positive actions that may arise from the direct instructions of law, contract, work relations, as well as cases, created by a person himself; b) possibility to realize them; c) absence of such actions.

\section{Acknowledgements}

The authors thank the anonymous reviewers and editor for their valuable contribution.

\section{Funding}

This research received no specific grant from any funding agency in the public, commercial, or not - for - profit sectors.

\section{Author Contributions}

The authors contributed equally to this work.

\section{Disclosure Statement}

The authors have not any competing financial, professional, or personal interests from other parties.

\section{References}

1. Antimonov, B.S., (1948). On the concept and meaning of causation in civil law, Proceedings of the scientific session of the All-Union Institute of Legal Sciences (1-6 July), Moskow: Legal publishing house of the Ministry of Justice of the USSR.

2. Antimonov, B.S., (1950). The value of the guilt of the victim in a civil violation, Moskow, State Legal Publication.

3. Antimonov, B.S., (1952). Civil liability for harm caused by a source of increased danger, Moskow, State Legal Publication.

4. Bobrova, D.V., (2002). Obligation to cause harm, Civil Law of Ukraine, Kiev, Yurinkom Inter.

5. Fleishyts, E.A., (1951). Obligations from harm and unjust enrichment. Moscow, State Publishing House of Legal Literature.

6. Fleishyts, E.A., (1951). Obligations from harm and unjust enrichment, Moscow, State Publishing House of Legal Literature. 
Buletsa, S., Hrinko, S., Hrinko, R., Anikina, H., (2020)

Wrongful omission as a condition for tort liabilities

7. Ioffe, O.S., (1951). Compensation Obligations. Second Edition, Leningrad, Publishing House of Leningrad State University, pp. 20-21.

8. Ioffe, O.S., (2003). Responsibility under Soviet Civil Law (First Edition), Selected Works, St. Petersburg, Publishing House Legal Center Press.

9. Kapitanska, C.A., (2005). Lawlessness as a form of legal conduct, Ph.D. thesis in Law: 12.00.01, Kyiv, P. 10.

10. Khannanov, R.A., (1978). Legal nature of inaction and causality, Soviet state and law, Volume 4, pp. 127-128.

11. Krasavchikov, O.O., (1966). Compensation for damage caused by a source of increased danger, Moskow, Legal Literature, P. 100.

12. Kudriavtsev, V.M., (1967). Illegal Inaction and Causation, Soviet state and law, Volume 5, pp. 28-29.

13. Matveev, H.K., (1955). Wines in Soviet Civil Law, Kiev, High school.

14. Novitskyi, I. B., Lunts, L. A, (1950). General doctrine of commitment, Moskow, Legal Publishing House.

15. Piontkovskyi, A. A., (1949). The problem of causation in law, Scientific notes of the AllUnion Institute of Legal Sciences, Volume IX.

16. Poohan, I., Polenak-Akimovskaya, M., (2000). Roman law, Moskow, ZERZALO Publishing House.

17. Prusakov, A. D., (2008). Action and inaction as a form of legally relevant behavior: Ph.D. thesis in Law: 12.00.01, Saratov.

18. Semiakin, M.N., (1973). Unlawful failure to act in obligations arising from harm. Problems of Civil Liability and Protection of Civil Rights. Sverdlovsk, pp. 66-68.

19. Sharhorodskyi, M.D., (1947). Crimes Against Life and Health. Moskow, Legal Publishing House.

20. Sharhorodskyi, M.D., (1956). Some questions of causation in the theory of law, Soviet state and law, Volume 7, pp. 48-51

21. Shevchenko, Ya.M., (1964). Property liability for harm caused by children under Soviet civil law, Ph.D. thesis in Law: 12.02.03, Kyiv.

22. Shevchenko, Ya.M., (1969). On the grounds of responsibility for the harm caused to children, Bulletin of the University of Kiev, Special issue, The works of legal scholars of Kyiv and Jagiellonian Univ, Issues of civil liability, Kiev: Publishing House of Kiev University, P. 89.

23. Tarkhov, V.O., (1973), Responsibility under Soviet Civil Law, Saratov, Saratov University Press, pp. 45-46.

24. Ter-Akopov, A. A., (1976). Definition of the essence of inaction, Soviet state and law, Volume 12, P. 73.

25. Timeik, H.F., (1966). Causation and the problem of inaction liability, Criminal law issues, Moskow, Publishing House of the All-Union Correspondence Institute of Law, P. 103.

26. Tsereteli, T.V., (1949). Causation in Criminal Law, Ph.D. thesis in Law: 12.00.08, P. 14. 
Buletsa, S., Hrinko, S., Hrinko, R., Anikina, H., (2020)

Wrongful omission as a condition for tort liabilities

\section{Notes:}

[1] Ioffe, O.S., 1951, Compensation Obligations. Second Edition, Leningrad, Publishing House of Leningrad State University, pp. 20-21.

[2] Novitskyi, I. B. \& Lunts, L. A., 1950, General doctrine of commitment, Moskow, Legal Publishing House, P. 314; Tarkhov, V.O., 1973, Responsibility under Soviet Civil Law, Saratov, Saratov University Press, pp. 45-46; Fleishyts, E.A., 1951, Obligations from harm and unjust enrichment, Moscow, State Publishing House of Legal Literature, P. 72; Sharhorodskyi, M.D., 1956, Some questions of causation in the theory of law, Soviet state and law, Volume 7, pp. 48-51; Sharhorodskyi, M.D., 1947, Crimes Against Life and Health. Moskow, Legal Publishing House, P. 98.

[3] Shevchenko, Ya.M., 1964, Property liability for harm caused by children under Soviet civil law, Ph.D. thesis in Law: 12.02.03, Kyiv, P. 8.

[4] Antimonov, B.S., 1952, Civil liability for harm caused by a source of increased danger, Moskow, State Legal Publication, P. 146; Antimonov, B.S., 1950, The value of the guilt of the victim in a civil violation, Moskow, State Legal Publication, P. 125.

[5] Novitskyi, I. B. \& Lunts, L. A., 1950, General doctrine of commitment, Moskow, Legal Publishing House, P. 314; Shevchenko, Ya.M., 1964, Property liability for harm caused by children under Soviet civil law, Ph.D. thesis in Law: 12.02.03. Kyiv, P. 8.

[6] Antimonov, B.S. 1948. On the concept and meaning of causation in civil law, Proceedings of the scientific session of the All-Union Institute of Legal Sciences (1-6 July), Moskow: Legal publishing house of the Ministry of Justice of the USSR, pp. 62-79; Antimonov, B.S., 1950 , The value of the guilt of the victim in a civil violation, Moskow, State Legal Publication, pp. 144-145.

[7] Novitskyi, I. B. \& Lunts, L. A., 1950, General doctrine of commitment, Moskow, Legal Publishing House, P. 313.

[8] Piontkovskyi, A. A., 1949, The problem of causation in law, Scientific notes of the AllUnion Institute of Legal Sciences, Volume IX, P. 88.

[9] Novitskyi, I. B. \& Lunts, L. A., 1950, General doctrine of commitment, Moskow, Legal Publishing House, P. 313.

[10] Ioffe, O.S., 2003, Responsibility under Soviet Civil Law (First Edition), Selected Works, St. Petersburg, Publishing House Legal Center Press, P. 455.

[11] Ioffe, O.S., 2003, Responsibility under Soviet Civil Law (First Edition), Selected Works. St. Petersburg, Publishing House Legal Center Press, P. 455; Matveev, H.K., 1955, Wines in Soviet Civil Law, Kiev, High school, P. 313; Novitskyi, I. B. \& Lunts, L. A., 1950, General doctrine of commitment. Moskow, Legal Publishing House, P. 131; Shevchenko, Ya.M., 1964, Property liability for harm caused by children under Soviet civil law, Ph.D. thesis in Law: 12.02.03, Kyiv, P. 8.

[12] Shevchenko, Ya.M., 1964, Property liability for harm caused by children under Soviet civil law, Ph.D. thesis in Law: 12.02.03, Kyiv, P. 8.

[13] Shevchenko, Ya.M., 1969, On the grounds of responsibility for the harm caused to children, Bulletin of the University of Kiev, Special issue, The works of legal scholars of Kyiv and Jagiellonian Univ, Issues of civil liability, Kiev: Publishing House of Kiev University, P. 89. 
Buletsa, S., Hrinko, S., Hrinko, R., Anikina, H., (2020)

Wrongful omission as a condition for tort liabilities

[14] Ioffe, O.S., 2003, Responsibility under Soviet Civil Law (First Edition), Selected Works, St. Petersburg, Publishing House Legal Center Press, P. 457.

[15] Poohan, I. \& Polenak-Akimovskaya, M., 2000, Roman law, Moskow, ZERZALO Publishing House, P. 276.

[16] Krasavchikov, O.O., 1966, Compensation for damage caused by a source of increased danger, Moskow, Legal Literature, P. 100.

[17] Kapitanska, C.A., 2005, Lawlessness as a form of legal conduct, Ph.D. thesis in Law: 12.00.01, Kyiv, P. 10.

[18] Prusakov, A. D., 2008, Action and inaction as a form of legally relevant behavior: Ph.D. thesis in Law: 12.00.01, Saratov, P. 32.

[19] Khannanov, R.A., 1978, Legal nature of inaction and causality, Soviet state and law, Volume 4, pp. 127-128.

[20] Antimonov, B.S., 1948, On the concept and meaning of causation in civil law. Proceedings of the scientific session of the All-Union Institute of Legal Sciences (1-6 July), Moskow, Legal publishing house of the Ministry of Justice of the USSR, pp. 62-79; Antimonov, B.S., 1950, The value of the guilt of the victim in a civil violation, Moskow, State Legal Publication, pp. 144-145.

[21] Fleishyts, E.A., 1951, Obligations from harm and unjust enrichment. Moscow, State Publishing House of Legal Literature, P. 71.

[22] Tarkhov, V.O., 1973, Responsibility under Soviet Civil Law, Saratov, Saratov University Press, pp. 45-46.

[23] Kudriavtsev, V.M., 1967, Illegal Inaction and Causation. Soviet state and law, Volume 5 , P. 36.

[24] Novitskyi, I. B. \& Lunts, L. A, 1950, General doctrine of commitment, Moskow, Legal Publishing House, P. 315.

[25] Tsereteli, T.V., 1949, Causation in Criminal Law, Ph.D. thesis in Law: 12.00.08, P. 14.

[26] Shevchenko, Ya.M., 1964, Property liability for harm caused by children under Soviet civil law, Ph.D. thesis in Law: 12.02.03, Kyiv, P. 8.

[27] Timeik, H.F., 1966, Causation and the problem of inaction liability, Criminal law issues, Moskow, Publishing House of the All-Union Correspondence Institute of Law, P. 103.

[28] Ioffe, O.S., 2003, Responsibility under Soviet Civil Law (First Edition), Selected Works, St. Petersburg, Publishing House Legal Center Press, P. 454.

[29] Kudriavtsev, V.M., 1967, Illegal Inaction and Causation, Soviet state and law, Volume 5, pp. 28-29.

[30] Ter-Akopov, A. A., 1976, Definition of the essence of inaction, Soviet state and law, Volume 12, P. 73.

[31] Prusakov, A. D., 2008, Action and inaction as a form of legally relevant behavior: Ph.D. thesis in Law: 12.00.01, Saratov, P. 27.

[32] Ioffe, O.S., 1951, Compensation Obligations. Second Edition, Leningrad, Publishing House of Leningrad State University, pp. 18-19.

[33] Ioffe, O.S., 1951, Compensation Obligations. Second Edition. Leningrad, Publishing House of Leningrad State University, pp. 18-19; Semiakin, M.N., 1973, Unlawful failure to act in obligations arising from harm. Problems of Civil Liability and Protection of Civil Rights. Sverdlovsk, pp. 66-68.

$142 S$ sciendo Journal of Legal Studies Volume 25 Issue 39/2020 
Buletsa, S., Hrinko, S., Hrinko, R., Anikina, H., (2020)

Wrongful omission as a condition for tort liabilities

[34] Bobrova, D.V., 2002, Obligation to cause harm, Civil Law of Ukraine, Kiev, Yurinkom Inter, P. 517.

[35] Ioffe, O.S., 2003, Responsibility under Soviet Civil Law (First Edition), Selected Works, St. Petersburg, Publishing House Legal Center Press, pp. 310-311. 